\title{
Data report: distribution and sources of tetraether lipids in Oligocene deposits from the western North Atlantic, IODP Sites U1406 and U1411'
}

\author{
Kasia K. Śliwińska, ${ }^{2,3}$ Anchelique Mets, ${ }^{3}$ and Stefan Schouten ${ }^{3,4}$
}

\begin{abstract}
Chapter contents
Abstract................... Introduction $\ldots \ldots \ldots \ldots \ldots \ldots \ldots \ldots$

Materials and methods............

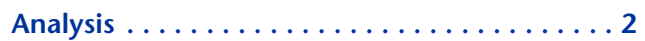

Results and discussion............. 3

Summary .................

Acknowledgments..............4

References.................4

Figures...................

Tables. ................... 11
\end{abstract}

1 Śliwińska, K.K., Mets, A., and Schouten, S., 2017. Data report: distribution and sources of tetraether lipids in Oligocene deposits from the western North Atlantic, IODP Sites U1406 and U1411. In Norris, R.D., Wilson, P.A., Blum, P., and the Expedition 342 Scientists, Proceedings of the Integrated Ocean Drilling Program, 342: College Station, TX (Integrated Ocean Drilling Program). doi:10.2204/iodp.proc.342.205.2017 ${ }^{2}$ Geological Survey of Denmark and Greenland (GEUS), Department of Stratigraphy, Øster Voldagde 10, DK-1350 Copenhagen K, Denmark. Correspondence author: kksı@geus.dk

${ }^{3}$ Also at Royal Netherlands Institute for Sea Research (NIOZ), Department of Marine Microbiology and Biogeochemistry and Utrecht University, PO Box 59, NL-1790 AB Den Burg, Texel, The Netherlands.

${ }^{4}$ Also at Department of Earth Sciences, Faculty of Geosciences, Utrecht University, The Netherlands.

\section{Abstract}

We have analyzed the distribution of glycerol dialkyl glycerol tetraether lipids (GDGTs) in the Oligocene succession recovered by Integrated Ocean Drilling Program Expedition 342. The two studied sites, U1406 and U1411, penetrate a highly expanded section of the upper Eocene-Oligocene-lower Miocene succession.

The branched isoprenoid tetraether (BIT) index varies between 0.2 and 0.85 , implying that there was a moderate to high influx of soil organic matter to both sites. Furthermore, during the late Oligocene (Chattian) the influx was lower than during the early Oligocene (Rupelian). The methane index (MI) and \%GDGT-0 index values suggest that methanotrophic Euryarchaeota and methanogenic archaea are not the main source of GDGTs, but rather marine Thaumarchaeota.

\section{Introduction}

Glycerol dialkyl glycerol tetraethers (GDGTs) are lipids spanning the cell membrane of archaea and certain bacteria. GDGTs are characterized by a large structural diversity and are observed in a wide range of environments (e.g., soil, peat, marine water column, and hot springs) (Schouten et al., 2013, and references cited therein). Structurally, GDGT membrane lipids are divided into two main groups: isoprenoid and branched GDGTs (Fig. F1).

Isoprenoid GDGTs (isoGDGTs) contain an isoprenoid carbon skeleton and derive from archaea (e.g., Schouten et al., 2000). One of the most ubiquitous isoGDGTs is crenarchaeol, a unique membrane lipid with a cyclohexane moiety. Crenarchaeol is produced by the marine archaea belonging to the phylum Thaumarchaeota (Sinninghe Damsté et al., 2002; Pitcher et al., 2011). Most species of Thaumarchaeota have been shown to be chemoautotrophs and are ammonia oxidizers (e.g., Könneke et al., 2005; Wuchter et al., 2006). The Thaumarchaeota also synthesize other common and environmentally dependent isoGDGTs: GDGT-0 (with no cyclopentane moiety) and GDGT-x (x denotes the number of cyclopentane moieties: 1, 2 or 3; Fig. F1). GDGT-0 is, however, also synthesized by many other archaea including methanogens (i.e., microorganisms that produce methane as a metabolic byproduct in anoxic conditions), which sometimes are important contributors to the sedimentary GDGT pool (e.g., Pancost et al., 2001; Blumenberg et al., 2004). It is also hypothesized that some smaller 
amounts of GDGT-1, GDGT-2, and GDGT-3 in sediment can be derived from the sedimentary archaeal methanogens or methanotrophic Euryarchaeota (Schouten et al., 2013, and references cited therein).

Branched GDGTs (brGDGTs) are primarily derived from soil bacteria (Weijers et al., 2006), presumed to be Acidobacteria (Sinninghe Damsté et al., 2011, 2014), and are also synthesized in situ in lakes (Tierney et al., 2010) and rivers (Zell et al., 2013; De Jonge et al., 2014). Furthermore, brGDGTs may also be produced in marine sediment (Sinninghe Damsté, 2016, and references cited therein).

Both isoGDGTs and brGDGTs are ubiquitous and rather well preserved in the sedimentary archives. Their omnipresence and good preservation in the geological record (for more details concerning the preservation, distribution, and origin of GDGTs, e.g., Schouten et al., 2004, 2007; Taylor et al., 2013; Inglis et al., 2015; Qin et al., 2015) are responsible for successful application of the GDGT-based indexes (e.g., TEX $_{86}$ and MBT/CBT paleotemperature proxies; for most recent $\mathrm{TEX}_{86}$ reviews see Pearson and Ingalls, 2013; Tierney and Tingley, 2015) in the paleoclimatic and paleoenvironmental studies of the Paleogene (Schouten et al., 2008; Bijl et al., 2009; Donders et al., 2009). However, the first and crucial step is to recognize the source and relative abundance of the studied GDGTs. To this end, several indexes have been developed. The branched isoprenoid tetraether (BIT) index is expressed as the ratio between brGDGTs and the crenarchaeol. The index is used as a proxy for estimating the relative input of soil and river organic material into marine settings (Hopmans et al., 2004; Huguet et al., 2009; Zell et al., 2014). BIT values span from close to 0 (absence of brGDGTs, typical for open marine environments) to 1 (absence of crenarchaeol, characteristic for mineral soils and peat) (Hopmans et al., 2004; Schouten et al., 2013). This proxy has successfully been applied in numerous paleoenvironmental studies (e.g., Donders et al., 2009; Śliwińska et al., 2014). The methane index (MI; the relative ratio of GDGTs 1-3 versus crenarchaeol; Zhang et al., 2011) and \%GDGT-0 (the ratio between GDGT-0 and crenarchaeol; Sinninghe Damsté et al., 2012) are used as indicators for the contribution of methanogenic and methanotrophic archaea. In "normal marine" environments $\mathrm{MI} \leq 0.3$, whereas in methane-rich environments MI can be as high as 1 (Zhang et al., 2011). Sinninghe Damsté et al. (2012) showed that if $\%$ GDGT-0 > 67\%, then GDGTs will most probably have a methanogenic source. These indicators have been successfully applied to constrain the sources and distribution of GDGTs in upper Paleogene sediment (e.g., Inglis et al., 2015).
Here, we evaluated the distribution and sources of GDGTs within sediment cores retrieved during Expedition 342 at the Newfoundland sediment drift. Operations during Expedition 342 succeeded in obtaining high-quality spliced records of upper Eocene to lower Miocene strata (see the "Site U1406" and "Site U1411" chapters [Norris et al., 2014a, 2014b]). The sites are located in the area where the modern Deep Western Boundary Current and the Gulf Stream Current transect (for details see Norris et al., 2011).

The purpose of our study was to analyze the depositional paleoenvironment of the Oligocene deposits from the Newfoundland sediment drift as well as to identify the source and the distribution of isoGDGTs and brGDGTs.

\section{Materials and methods}

Here we focused on two sites: U1406 $\left(40^{\circ} 21.0^{\prime} \mathrm{N}\right.$, $51^{\circ} 39.0^{\prime} \mathrm{W} ; 3798.9 \mathrm{~m}$ water depth) and $\mathrm{U} 1411$ $\left(41^{\circ} 37.1^{\prime} \mathrm{N}, 4^{\circ} 00^{\prime} \mathrm{W} ; \sim 3300 \mathrm{~m}\right.$ water depth) cored during Expedition 342. Site U1406 is located at JAnomaly Ridge (Fig. F2). In the present study, we have applied a revised age model (van Peer et al., submitted). The investigated interval consists of carbonate-rich deposits spanning the middle Oligocene from Chrons C11r to C8n.2n as well as the Oligocene-Miocene transition (Fig. F3). Site U1411 is located at the southeast Newfoundland Ridge (Fig. F2). The studied interval consists of clay-rich sediment referred to lower to middle Oligocene (Chrons C13rC8n.2n; Fig. F4). Our results are plotted against the shipboard magnetostratigraphic age model (see the "Site U1411" chapter [Norris et al., 2014b]) on Figure F4.

\section{Analysis}

For the organic geochemical analysis of GDGTs, 79 sediment samples (45 samples from Site U1406 and 34 samples from Site U1411; Tables T1, T2) were collected. Samples were freeze-dried and then mechanically ground. From 10 to $20 \mathrm{~g}$ of sediment was taken for further analysis. The total lipid extract was obtained by the accelerated solvent extraction (ASE) technique using dichloromethane/methanol (9:1 [v/ v]) with the following settings:

$$
\begin{aligned}
& \text { Pressure = } 1500 \text { psi; } \\
& \text { Static = } 5 \mathrm{~min} ; \\
& \text { Flush }=60 \% ; \\
& \text { Purge }=60 \mathrm{~s} ; \text { and } \\
& \text { Cycles = } 3 .
\end{aligned}
$$

Subsequently, the extract was separated over an activated $\mathrm{Al}_{2} \mathrm{O}_{3}$ column into an apolar (hexane/di- 
chloromethane; 9:1 [v/v]) and a polar (dichloromethane/methanol; $1: 1[\mathrm{v} / \mathrm{v}]$ ) fraction. The polar fraction, prior to GDGT analysis, was dissolved in hexane-isopropanol $(99: 1[\mathrm{v} / \mathrm{v}])$ and filtered over a $0.4 \mu \mathrm{m}$ polytetrafluoroethylene filter. GDGTs were analyzed using high-performance liquid chromatography-mass spectrometry (HPLC-MS) as described by Schouten et al. (2007). Briefly, an Agilent (Palo Alto, CA, USA) 1100 HPLC high-sensitivity mass-selective detector (MSD SL) was used. Compounds were separated using a Prevail cyano column $(150 \times 2.1 \mathrm{~mm} ; 3$ $\mu \mathrm{m}$; Alltech, Deerfield, IL, USA) maintained at $30^{\circ} \mathrm{C}$. GDGTs were eluted isocratically with $99 \%$ hexane and $1 \%$ isopropanol for $5 \mathrm{~min}$, followed by a linear gradient to $98 \%$ hexane and $2 \%$ isopropanol at a flow rate of $0.2 \mathrm{~mL} / \mathrm{min}$. Detection was achieved using single-ion monitoring. Relative qualification of the compounds was achieved by manual integration of the peaks in the mass chromatograms in the Agilent ChemStation manager software.

The BIT index values were calculated as described by Hopmans et al. (2004):

$$
\begin{gathered}
\text { BIT }=(\text { GDGT-Ia + GDGT-IIa + GDGT-IIIa }) / \\
(\text { GDGT-Ia + GDGT-IIa + GDGT-IIIa + crenarchaeol }) .
\end{gathered}
$$

The roman numerals refer to individual brGDGT structures as shown in Figure F1 (for details see Schouten et al., 2013).

The MI was calculated following the equation given by Zhang et al. (2011):

$$
\mathrm{MI}=(\mathrm{GDGT}-1+\mathrm{GDGT}-2+\text { GDGT-3) } /
$$

(GDGT-1 + GDGT-2 + GDGT-3 + crenarchaeol + crenarchaeol regio-isomer).

The \%GDGT-0 index was calculated following the equation given by Sinninghe Damsté et al. (2012):

$$
\begin{gathered}
\% \text { GDGT-0 }=(\text { GDGT-0/(GDGT-0 + } \\
\text { crenarchaeol }) \times 100 .
\end{gathered}
$$

\section{Results and discussion}

\section{Continental input of GDGTs}

At Site U1406 in the lower part of the studied succession (Chrons $\mathrm{C} 11 \mathrm{r}-\mathrm{C} 9 \mathrm{n}$ ), the BIT index shows a gradually decreasing trend from $\sim 0.55$ to $\sim 0.2$, spanned by two local maxima within Chrons C11n.2n $(0.8 \leq$ BIT $\leq 0.88)$ and C9n $(0.44 \leq$ BIT $\leq$ 0.65). Within Chrons C8r and C8n.2n, the BIT index shows moderate values scattered between 0.25 and 0.65 . Across the Oligocene-Miocene transition, the BIT index shows a sharp decrease from 0.6 to 0.1 (Fig. F3).
The value range for the BIT index at Site U1411 lies between 0.3 and 0.6 and shows elevated values $(0.55-0.65)$ in the interval from the top of Chron C13n to the middle part of Chron C12r (Fig. F4).

The overall moderate to high BIT values indicate that in the GDGT pool a substantial part of the GDGTs are terrestrially derived because open marine sediment typically has BIT values $<0.1$ (Schouten et al., 2013, and references cited therein). In general, we observe that BIT index values are higher in the uppermost Rupelian than in the lower Chattian (Figs. F3, F4) and thus may imply a decrease in the input of soil organic matter to the site around the Rupelian/Chattian boundary.

\section{Impact of methane cycling}

At both sites, the MI is between 0.2 and 0.27 . The values for both studied successions are fairly similar to the average values for Eocene-Oligocene deposits shown by Inglis et al. (2015). This suggests that the Oligocene strata at the Newfoundland sediment drift are, like the majority of the age-equivalent deposits, relatively unaffected by the input of GDGTs from Euryarchaeota, which are associated with the anaerobic oxidation of methane (Pancost et al., 2001; Blumenberg et al., 2004; Inglis et al., 2015).

At Site U1406, the \%GDGT-0 index shows values between $30 \%$ and $49 \%$ (Fig. F3), with no apparent trend in time. One local maximum within Chron C11n.2n with index values of up to $71.5 \%$ (Sample 342-U1406A-19H-2, 76-78 cm) was observed. Furthermore, two isolated samples show values $>52 \%$ (147.84 meters composite depth [mcd], Sample 342U1406B-15H-4, 76-78 cm; and 167.09 mcd, Sample $17 \mathrm{H}-3,76-78 \mathrm{~cm})$. At Site U1411, the \%GDGT-0 index values range from $37 \%$ to $45 \%$. We observed a gradual, gently increasing trend from $37 \%$ in Chron C13r (the base of the studied succession at Site U1411) to $44 \%$ in the lower part of Chron C12r. From the middle part of Chron C12r to Chron C8n.2n (the top of the studied succession at Site U1411), the values are rather stable, between $40 \%$ and $45 \%$. One sample $(54.62 \mathrm{mcd}$, Sample 342U1411B-7H-4, 26-30 cm) shows a \%GDGT-0 index value of $50 \%$.

Our results indicate that only one sediment sample has a \%GDGT-0 > 67\% (Sample 342-U1406A-19H-2, 76-78 cm), which suggests that some of the GDGT may be derived from methanogenic archaea in that particular sample. In contrast, all other sediment shows no sign of input of methanogenic archaea. Thus, the combined MI and \%GDGT-0 index indicate that there was no significant impact of archaea involved in the methane cycle on the distribution of GDGTs and that most of the GDGTs are likely to de- 
rive from Thaumarchaeota, especially since crenarchaeol, the biomarker for Thaumarchaeota, is present in relatively high abundances (40\%-50\%; Tables T1, T2). Only in five samples from Site U1406 were abundances $<40 \%$, but these samples also had high BIT values (0.6-0.8). This agrees with the general observation that the \%crenarchaeol (of total isoGDGTs) is much lower in soil organic matter than marine organic matter (see compilation in Schouten et al., 2013).

\section{Summary}

In the present study we analyzed three organic geochemical proxies: the BIT, MI, and \%GDGT-0 indexes. The results imply that most of the isoGDGTs preserved in the Oligocene deposits on the Newfoundland sediment drifts are derived from Thaumarchaeota. Furthermore, a moderate to high amount of brGDGTs were observed, suggesting a continental source of lipids in the marine sediment of the two studied sites (U1406 and U1411).

\section{Acknowledgments}

This research used samples provided by IODP. We thank the Co-Chief Scientists Richard D. Norris and Paul A. Wilson and the participants of the sampling party at Bremen (IODP Expedition 342). We especially acknowledge Walter Hale and Diederik Liebrand for their assistance in collecting samples. We thank Tim van Peer for converting the depths into the updated age model at Site U1406. We greatly appreciate the review of this manuscript by Dr. David Naafs.

Financial support for this research was provided by the Danish Council for Independent Research/Natural Sciences (DFF/FNU; Grant 11-107497) to K.K.Ś., and the Netherlands Earth System Science Centre (NESSC) funded by the Ministry of Education, Culture and Science (OCW) (to S.S.).

\section{References}

Bijl, P.K., Schouten, S., Sluijs, A., Reichart, G.-J., Zachos, J.C., and Brinkhuis, H., 2009. Early Palaeogene temperature evolution of the southwest Pacific Ocean. Nature, 461(7265):776-779. http://dx.doi.org/10.1038/ nature08399

Blumenberg, M., Seifert, R., Reitner, J., Pape, T., and Michaelis, W., 2004. Membrane lipid patterns typify distinct anaerobic methanotrophic consortia. Proceedings of the National Academy of Science of the United States of America, 101(30):11111-11116. http://dx.doi.org/ 10.1073/pnas.0401188101
De Jonge, C., Stadnitskaia, A., Hopmans, E.C., Cherkashov, G., Fedotov, A., and Sinninghe Damsté, J.S., 2014. In situ produced branched glycerol dialkyl glycerol tetraethers in suspended particulate matter from the Yenisei River, Eastern Siberia. Geochimica et Cosmochimica Acta, 125:476-491. http://dx.doi.org/10.1016/ j.gca.2013.10.031

Donders, T.H., Weijers, J.W.H., Munsterman, D.K., Kloosterboer-van Hoeve, M.L., Buckles, L.K., Pancost, R.D., Schouten, S., Sinninghe Damsté, J.S., and Brinkhuis, H., 2009. Strong climate coupling of terrestrial and marine environments in the Miocene of northwest Europe. Earth and Planetary Science Letters, 281(3-4):215-225. http://dx.doi.org/10.1016/j.epsl.2009.02.034

Expedition 342 Scientists, 2012. Paleogene Newfoundland sediment drifts. Integrated Ocean Drilling Program Preliminary Report, 342. http://dx.doi.org/10.2204/ iodp.pr.342.2012

Hopmans, E.C., Weijers, J.W.H., Schefuß, E., Herfort, L., Sinninghe Damsté, J.S., and Schouten, S., 2004. A novel proxy for terrestrial organic matter in sediments based on branched and isoprenoid tetraether lipids. Earth and Planetary Science Letters, 224(1-2):107-116. http:// dx.doi.org/10.1016/j.epsl.2004.05.012

Huguet, C., Kim, J.-H., de Lange, G.J., Sinninghe Damsté, J.S., and Schouten, S., 2009. Effects of long term oxic degradation on the $U^{K^{\prime}}{ }_{37}, \mathrm{TEX} \mathrm{X}_{86}$ and BIT organic proxies. Organic Geochemistry, 40(12):1188-1194. http:// dx.doi.org/10.1016/j.orggeochem.2009.09.003

Inglis, G.N., Farnsworth, A., Lunt, D., Foster, G.L., Hollis, C.J., Pagani, M., Jardine, P.E., Pearson, P.N., Markwick, P., Galsworthy, A.M.J., Raynham, L., Taylor, K.W.R., and Pancost, R.D., 2015. Descent toward the icehouse: Eocene sea surface cooling inferred from GDGT distributions. Paleoceanography, 30(7):1000-1020. http:// dx.doi.org/10.1002/2014PA002723

Könneke, M., Bernhard, A.E., de la Torre, J.R., Walker, C.B., Waterbury, J.B., and Stahl, D.A., 2005. Isolation of an autotrophic ammonia-oxidizing marine archaeon. Nature, 437(7058):543-546. http://dx.doi.org/ 10.1038/nature03911

Norris, R.D., Wilson, P.A., and Blum, P., 2011. Paleogene Newfoundland sediment drifts. Integrated Ocean Drilling Program Scientific Prospectus, 342. http://dx.doi.org/ 10.2204/iodp.sp.342.2011

Norris, R.D., Wilson, P.A., Blum, P., Fehr, A., Agnini, C., Bornemann, A., Boulila, S., Bown, P.R., Cournede, C., Friedrich, O., Ghosh, A.K., Hollis, C.J., Hull, P.M., Jo, K., Junium, C.K., Kaneko, M., Liebrand, D., Lippert, P.C., Liu, Z., Matsui, H., Moriya, K., Nishi, H., Opdyke, B.N., Penman, D., Romans, B., Scher, H.D., Sexton, P., Takagi, H., Turner, S.K., Whiteside, J.H., Yamaguchi, T., and Yamamoto, Y., 2014a. Site U1406. In Norris, R.D., Wilson, P.A., Blum, P., and the Expedition 342 Scientists, Proceedings of the Integrated Ocean Drilling Program, 342: College Station, TX (Integrated Ocean Drilling Program). http://dx.doi.org/10.2204/ iodp.proc.342.107.2014 
Norris, R.D., Wilson, P.A., Blum, P., Fehr, A., Agnini, C., Bornemann, A., Boulila, S., Bown, P.R., Cournede, C., Friedrich, O., Ghosh, A.K., Hollis, C.J., Hull, P.M., Jo, K., Junium, C.K., Kaneko, M., Liebrand, D., Lippert, P.C., Liu, Z., Matsui, H., Moriya, K., Nishi, H., Opdyke, B.N., Penman, D., Romans, B., Scher, H.D., Sexton, P., Takagi, H., Turner, S.K., Whiteside, J.H., Yamaguchi, T., and Yamamoto, Y., 2014b. Site U1411. In Norris, R.D., Wilson, P.A., Blum, P., and the Expedition 342 Scientists, Proceedings of the Integrated Ocean Drilling Program, 342: College Station, TX (Integrated Ocean Drilling Program). http://dx.doi.org/10.2204/ iodp.proc.342.112.2014

Pancost, R.D., Hopmans, E.C., Sinninghe Damsté, J.S., and the MEDINAUT Shipboard Scientific Party, 2001. Archaeal lipids in Mediterranean cold seeps: molecular proxies for anaerobic methane oxidation. Geochimica et Cosmochimica Acta, 65(10):1611-1627. http:// dx.doi.org/10.1016/S0016-7037(00)00562-7

Pearson, A., and Ingalls, A.E., 2013. Assessing the use of archaeal lipids as marine environmental proxies. Annual Review of Earth and Planetary Sciences, 41:359-384. http:/ /dx.doi.org/10.1146/annurev-earth-050212-123947

Pitcher, A., Wuchter, C., Siedenberg, K., Schouten, S., and Sinninghe Damsté, J.S., 2011. Crenarchaeol tracks winter blooms of ammonia-oxidizing Thaumarchaeota in the coastal North Sea. Limnology and Oceanography, 56(6):2308-2318. http://dx.doi.org/10.4319/ 10.2011.56.6.2308

Qin, W., Carlson, L.T., Armbrust, E.V., Devol, A.H., Moffett, J.W., Stahl, D.A., and Ingalls, A.E., 2015. Confounding effects of oxygen and temperature on the $\mathrm{TEX}_{86}$ signature of marine Thaumarchaeota. Proceedings of the National Academy of Sciences of the United States of America, 112(35):10979-10984. http://dx.doi.org/10.1073/ pnas. 1501568112

Schouten, S., Eldrett, J., Greenwood, D.R., Harding, I., Baas, M., and Sinninghe Damsté, J.S., 2008. Onset of long-term cooling of Greenland near the Eocene-Oligocene boundary as revealed by branched tetraether lipids. Geology, 36(2):147-150. http://dx.doi.org/ 10.1130/G24332A.1

Schouten, S., Hopmans, E.C., Pancost, R.D., and Sinninghe Damsté, J.S., 2000. Widespread occurrence of structurally diverse tetraether membrane lipids: evidence for the ubiquitous presence of low-temperature relatives of hyperthermophiles. Proceedings of the National Academy of Science, 97(26):14421-14426. http://dx.doi.org/ 10.1073/pnas.97.26.14421

Schouten, S., Hopmans, E.C., and Sinninghe Damsté, J.S., 2004. The effect of maturity and depositional redox conditions on archaeal tetraether lipid paleothermometry. Organic Geochemistry, 35(5):567-571. http:// dx.doi.org/10.1016/j.orggeochem.2004.01.012

Schouten, S., Hopmans, E.C., and Sinninghe Damsté, J.S., 2013. The organic geochemistry of glycerol dialkyl glycerol tetraether lipids: a review. Organic Geochemistry,
54:19-61. http://dx.doi.org/10.1016/j.orggeochem.2012.09.006

Schouten, S., Huguet, C., Hopmans, E.C., Kienhuis, M.V.M., and Sinninghe Damsté, J.S., 2007. Analytical methodology for $\mathrm{TEX}_{86}$ paleothermometry by high-performance liquid chromatography/atmospheric pressure chemical ionization-mass spectrometry. Analytical Chemistry, 79(7):2940-2944. http://dx.doi.org/ $10.1021 / a c 062339 v$

Sinninghe Damsté, J.S., 2016. Spatial heterogeneity of sources of branched tetraethers in shelf systems: the geochemistry of tetraethers in the Berau River delta (Kalimantan, Indonesia). Geochimica et Cosmochimica Acta, 186:13-31. http://dx.doi.org/10.1016/ j.gca.2016.04.033

Sinninghe Damsté, J.S., Ossebaar, J., Schouten, S., and Verschuren, D., 2012. Distribution of tetraether lipids in the 25-ka sedimentary record of Lake Challa: extracting reliable $\mathrm{TEX}_{86}$ and $\mathrm{MBT} / \mathrm{CBT}$ palaeotemperatures from an equatorial African lake. Quaternary Science Reviews, 50:43-54. http://dx.doi.org/10.1016/j.quascirev.2012.07.001

Sinninghe Damsté, J.S., Rijpstra, W.I.C., Hopmans, E.C., Foesel, B.U., Wüst, P.K., Overmann, J., Tank, M., Bryant, D.A., Dunfield, P.F., Houghton, K., and Stott, M.B., 2014. Ether- and ester-bound iso-diabolic acid and other lipids in members of acidobacteria subdivision 4 . Applied and Environmental Microbiology, 80(17):52075218. http://dx.doi.org/10.1128/AEM.01066-14

Sinninghe Damsté, J.S., Rijpstra, W.I.C., Hopmans, E.C., Weijers, J.W.H., Foesel, B.U., Overmann, J., and Dedysh, S.N., 2011. 13,16-dimethyl octacosanedioic acid (isodiabolic acid), a common membrane-spanning lipid of acidobacteria subdivisions 1 and 3. Applied and Environmental Microbiology, 77(12):4147-4154. http:// dx.doi.org/10.1128/AEM.00466-11

Sinninghe Damsté, J.S., Schouten, S., Hopmans, E.C., van Duin, A.C.T., and Geenevasen, J.A.J., 2002. Crenarchaeol: the characteristic core glycerol dibiphytanyl glycerol tetraether membrane lipid of cosmopolitan pelagic crenarchaeota. Journal of Lipid Research, 43(10):1641-1651. http://dx.doi.org/10.1194/ jlr.M200148-JLR200

Śliwińska, K.K., Dybkjær, K., Schoon, P.L., Beyer, C., King, C., Schouten, S., and Nielsen, O.B., 2014. Paleoclimatic and paleoenvironmental records of the Oligocene-Miocene transition, central Jylland, Denmark. Marine Geology, 350:1-15. http://dx.doi.org/10.1016/ j.margeo.2013.12.014

Taylor, K.W.R., Huber, M., Hollis, C.J., Hernandez-Sanchez, M.T., and Pancost, R.D., 2013. Re-evaluating modern and Palaeogene GDGT distributions: implications for SST reconstructions. Global and Planetary Change, 108:158-174. https://doi.org/10.1016/j.gloplacha.2013.06.011

Tierney, J.E., Russell, J.M., Eggermont, H., Hopmans, E.C., Verschuren, D., and Sinninghe Damsté, J.S., 2010. Envi- 
ronmental controls on branched tetraether lipid distributions in tropical East African lake sediments. Geochimica et Cosmochimica Acta, 74(17):4902-4918. http://dx.doi.org/10.1016/j.gca.2010.06.002

Tierney, J.E., and Tingley, M.P., 2015. A TEX 86 surface sediment database and extended Bayesian calibration. Scientific Data, 2:150029. http://dx.doi.org/10.1038/ sdata.2015.29

van Peer, T.E., Liebrand, D., Xuan, C., Lippert, P.C., Agnini, C., Blum, N., Blum, P., Bown, P.R., Greenop, R., Kordesch, W.E.C., Leonhardt, D., Friedrich, O., and Wilson, P.A., submitted. Revised composite depth scale, splice and magnetic stratigraphy for IODP Site U1406. Proceedings of the Integrated Ocean Drilling Program.

Weijers, J.W., Schouten, S., Hopmans, E.C., Geenevasen, J.A., David, O.R., Coleman, J.M., Pancost, R.D., and Sinninghe Damsté, J.S., 2006. Membrane lipids of mesophilic anaerobic bacteria thriving in peats have typical archaeal traits. Environmental Microbiology, 8(4):648-657. http://dx.doi.org/10.1111/j.1462-2920.2005.00941.x

Wuchter, C., Abbas, B., Coolen, M.J.L., Herfort, L., Van Bleijswijk, J., Timmers, P., Strous, M., Teira, E., Herndl, G.J., Middelburg, J.J., Schouten, S., and Sinninghe Damsté, J.S., 2006. Archaeal nitrification in the ocean. Proceedings of the National Academy of Sciences of the United States of America, 103(33):12317-12322. http:// dx.doi.org/10.1073/pnas.0600756103
Zell, C., Kim, J.-H., Hollander, D., Lorenzoni, L., Baker, P., Silva, C.G., Nittrouer, C., and Sinninghe Damsté, J.S., 2014. Sources and distributions of branched and isoprenoid tetraether lipids on the Amazon shelf and fan: implications for the use of GDGT-based proxies in marine sediments. Geochimica et Cosmochimica Acta, 139:293-312. http://dx.doi.org/10.1016/ j.gca.2014.04.038

Zell, C., Kim, J.-H., Moreira-Turcq, P., Abril, G., Hopmans, E.C., Bonnet, M.-P., Lima Sobrinho, R., and Sinninghe Damsté, J.S., 2013. Disentangling the origins of branched tetraether lipids and crenarchaeol in the lower Amazon River: implications for GDGT-based proxies. Limnology and Oceanography, 58(1):343-353. http://dx.doi.org/10.4319/1o.2013.58.1.0343

Zhang, Y.G., Zhang, C.L., Liu, X.-L., Li, L., Hinrichs, K.-U., and Noakes, J.E., 2011. Methane index: a tetraether archaeal lipid biomarker indicator for detecting the instability of marine gas hydrates. Earth and Planetary Science Letters, 307(3-4):525-534. http://dx.doi.org/ 10.1016/j.epsl.2011.05.031

Initial receipt: 16 September 2016

Acceptance: 28 February 2017

Publication: 19 April 2017

MS 342-205 
Figure F1. Molecular structures of (A) isoprenoid and (B) branched glycerol dialkyl glycerol tetraether lipids (GDGTs) discussed in the text. Values of associated $[\mathrm{M}+\mathrm{H}]+$ ions for each GDGT are shown in parentheses.

A Isoprenoid GDGTs

GDGT-0

GDGT-1

$(\mathrm{m} / \mathrm{z1302)}$

$(\mathrm{m} / \mathrm{z1300)}$
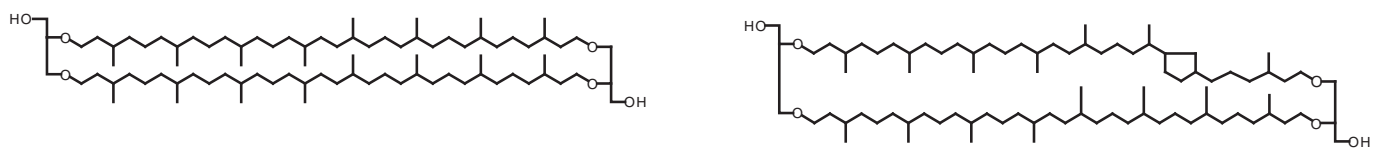

GDGT-2

GDGT-3

$(\mathrm{m} / \mathrm{z} 1298)$

$(m / z 1296)$
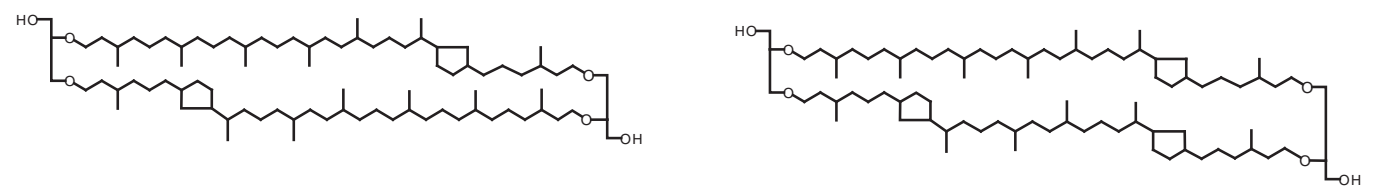

Crenarchaeol

Crenarchaeol regio-isomer

( $\mathrm{m} / \mathrm{z} 1292)$

$(m / z 1292)$
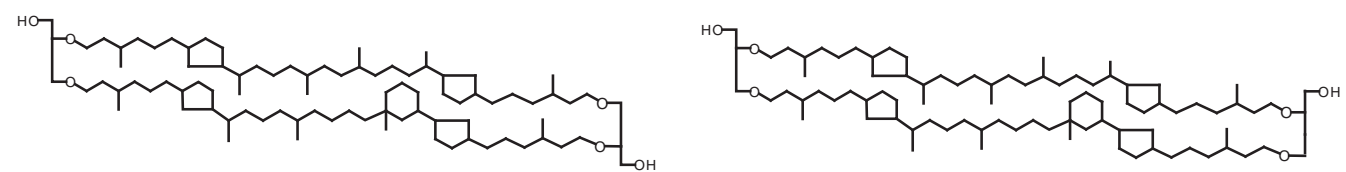

B

Branched GDGTs

GDGT-Ia

GDGT-Ila

( $\mathrm{m} / \mathrm{z} 1022)$

$(\mathrm{m} / \mathrm{z} 1036)$
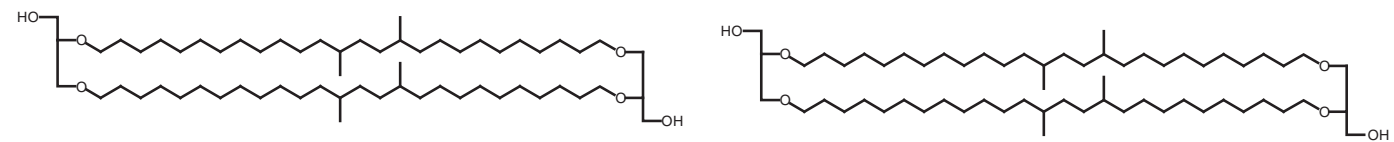

GDGT-IIIa

$(\mathrm{m} / \mathrm{z1050)}$

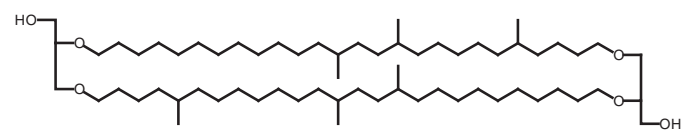


Figure F2. Bathymetry for the Newfoundland ridges. Black circles = Site U1406 and U1411 locations. Modified from Norris et al., 2011.

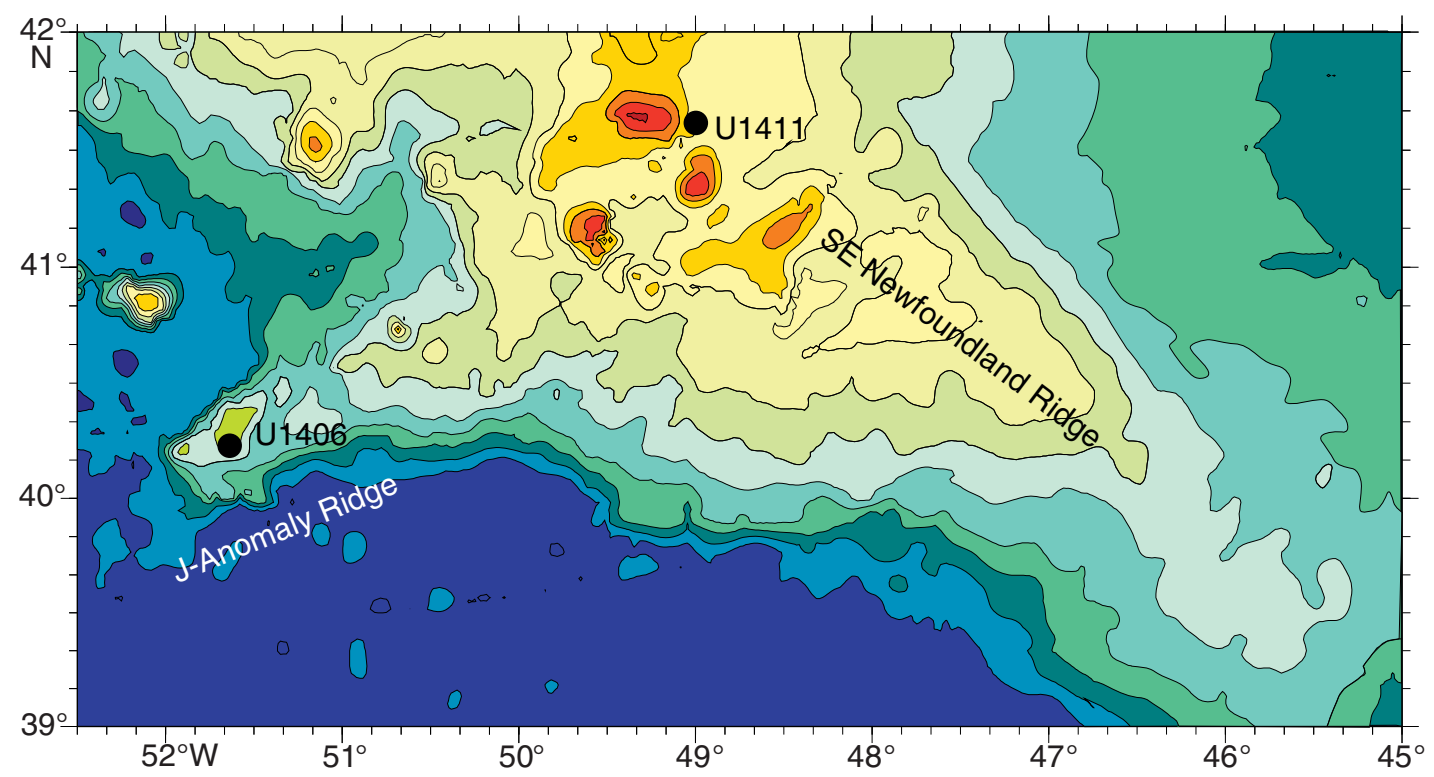


Figure F3. Methane index (MI), branched isoprenoid tetraether (BIT) index, and \%GDGT-0 index, Site U1406. Magnetostratigraphy is from the revised age model (van Peer et al., submitted). An interval with microfaults and possible slumping was positioned after van Peer et al. (submitted). GDGT = glycerol dialkyl glycerol tetraether lipids.

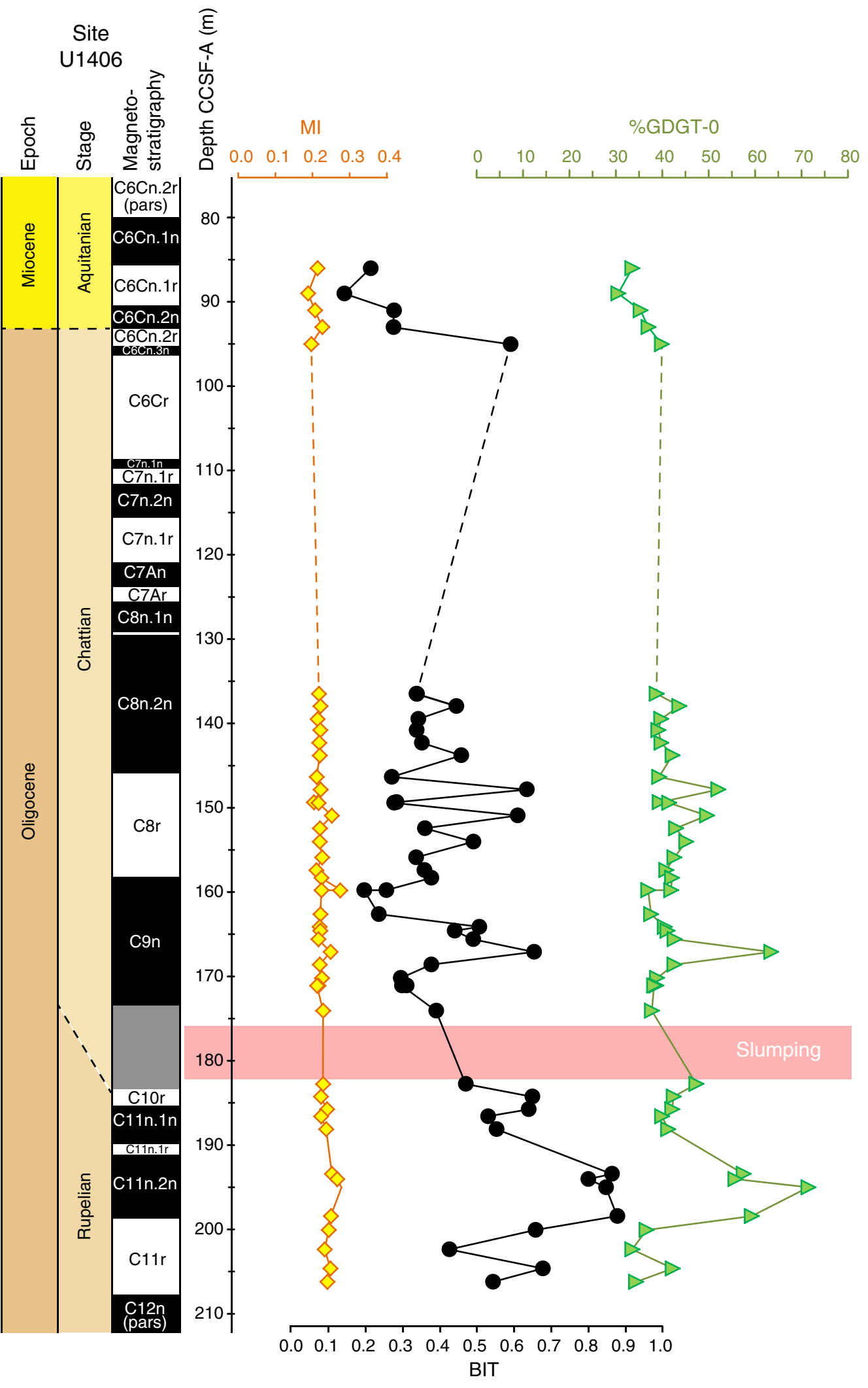


Figure F4. Methane index (MI), branched isoprenoid tetraether (BIT) index, and \%GDGT-0 index, Site U1411. Magnetostratigraphy is from shipboard data (Expedition 342 Scientists, 2012). GDGT = glycerol dialkyl glycerol tetraether lipids.

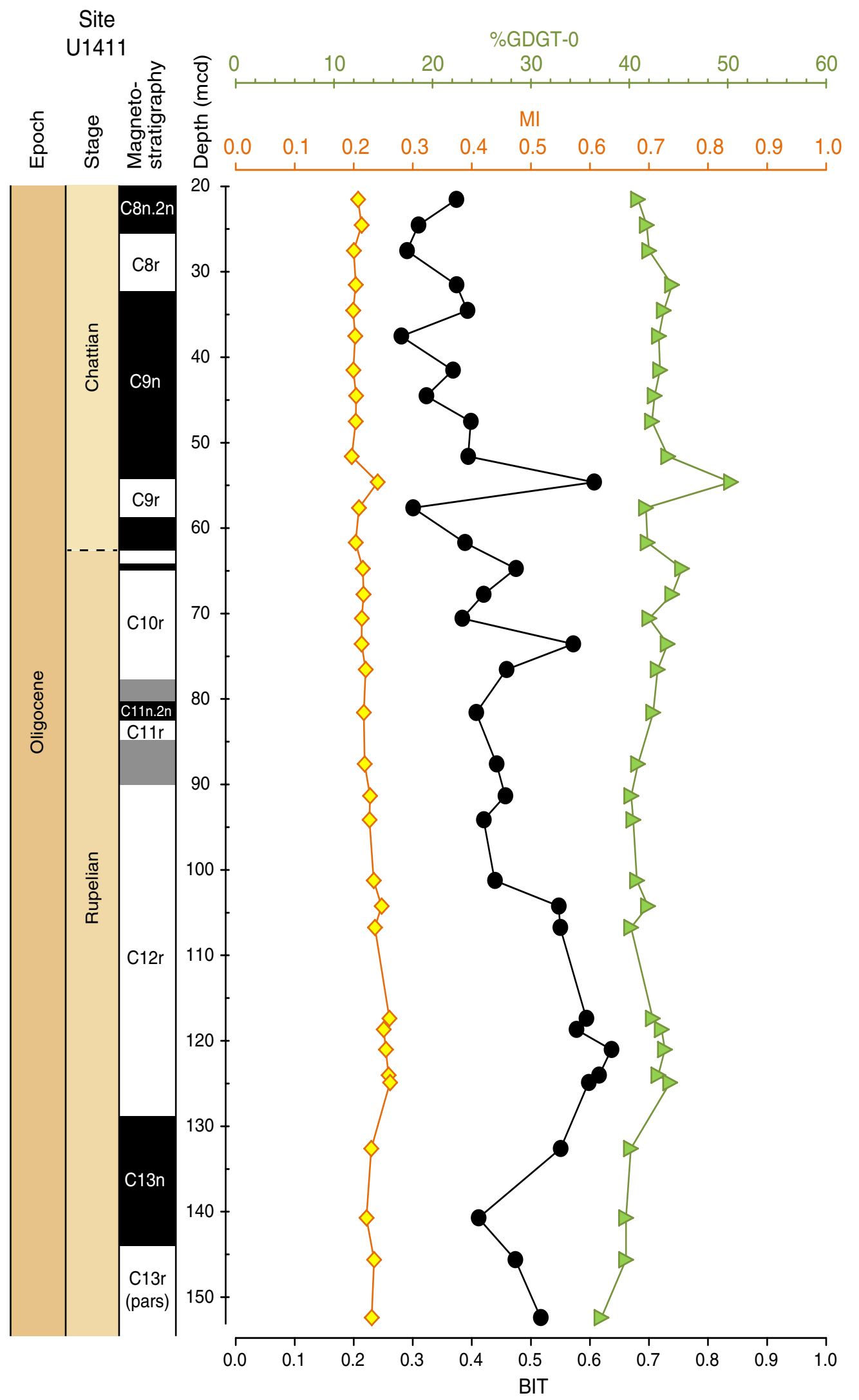


Table T1. Sample positions, depths, and analysis results, Site U1406.

\begin{tabular}{|c|c|c|c|c|c|}
\hline $\begin{array}{l}\text { Hole, core, section, } \\
\text { interval }(\mathrm{cm})\end{array}$ & $\begin{array}{l}\text { Revised top depth } \\
\text { CCSF-A }(m)\end{array}$ & BIT & MI & $\%$ GDGT-0 & \%crenarchaeol \\
\hline \multicolumn{6}{|l|}{$342-$} \\
\hline U1406A-9H-4, 31.5-33.5 & 85.980 & 0.21 & 0.21 & 33.4 & 52.5 \\
\hline U1406A-9H-2, 32-34 & 88.985 & 0.14 & 0.19 & 30.4 & 52.6 \\
\hline U1406C-9H-1, 124-127 & 90.980 & 0.28 & 0.21 & 35.2 & 52.0 \\
\hline U1406C-9H-3, 24-26 & 92.980 & 0.27 & 0.23 & 36.9 & 50.0 \\
\hline U1406C-9H-4, 56-58 & 94.800 & 0.59 & 0.20 & 39.8 & 49.4 \\
\hline U1406B-14H-4, 80-82 & 136.480 & 0.34 & 0.22 & 38.8 & 49.2 \\
\hline U1406B-14H-5, 76-78 & 137.940 & 0.44 & 0.22 & 43.7 & 45.9 \\
\hline U1406B-14H-6, 80-82 & 139.480 & 0.34 & 0.21 & 39.8 & 49.0 \\
\hline U1406C-15H-2, 80-82 & 140.790 & 0.34 & 0.22 & 39.1 & 48.9 \\
\hline U1406C-15H-3, 80-82 & 142.290 & 0.35 & 0.22 & 39.8 & 48.7 \\
\hline U1406C-15H-4, 80-82 & 143.790 & 0.46 & 0.22 & 42.2 & 47.1 \\
\hline U1406B-15H-3, 76-78 & 146.340 & 0.27 & 0.21 & 39.3 & 49.4 \\
\hline U1406B-15H-4, 76-78 & 147.840 & 0.63 & 0.22 & 52.1 & 40.3 \\
\hline U1406B-15H-5, 76-78 & 149.340 & 0.28 & 0.20 & 39.4 & 49.8 \\
\hline U1406A-15H-2, 76-78 & 149.420 & 0.28 & 0.22 & 41.5 & 47.8 \\
\hline U1406A-15H-3, 76-78 & 150.920 & 0.61 & 0.25 & 49.6 & 40.8 \\
\hline U1406A-15H-4, 76-78 & 152.440 & 0.36 & 0.22 & 42.9 & 46.7 \\
\hline U1406A-15H-5, 80-82 & 154.026 & 0.49 & 0.22 & 45.1 & 45.1 \\
\hline U1406C-16H-5, 76-78 & 155.890 & 0.34 & 0.23 & 42.6 & 46.6 \\
\hline U1406C-16H-6, 76-78 & 157.400 & 0.36 & 0.21 & 40.8 & 48.4 \\
\hline U1406B-16H-4, 80-83* & 158.310 & 0.38 & 0.22 & 42.1 & 46.8 \\
\hline U1406B-16H-5, 76-79 & 159.780 & 0.26 & 0.28 & 41.9 & 43.7 \\
\hline U1406B-16H-5, 76-79 & 159.780 & 0.20 & 0.22 & 37.0 & 50.1 \\
\hline U1406A-16H-4, 77-80 & 162.620 & 0.24 & 0.22 & 37.6 & 49.7 \\
\hline U1406A-16H-5, 77-80 & 164.120 & 0.51 & 0.22 & 40.5 & 47.9 \\
\hline U1406B-17H-1, 76-79 & 164.090 & 0.44 & 0.22 & 41.1 & 47.5 \\
\hline U1406B-17H-2, 76-79 & 165.590 & 0.49 & 0.22 & 42.6 & 46.9 \\
\hline U1406B-17H-3, 76-79 & 167.090 & 0.65 & 0.25 & 63.4 & 31.3 \\
\hline U1406B-17H-4, 76-79 & 168.590 & 0.38 & 0.22 & 42.6 & 46.9 \\
\hline U1406B-17H-5, 86-89 & 170.190 & 0.29 & 0.22 & 38.8 & 48.8 \\
\hline U1406A-17H-2, 79-82 & 171.090 & 0.31 & 0.22 & 38.7 & 49.4 \\
\hline U1406A-17H-4, 77-80 & 174.070 & 0.39 & 0.23 & 37.8 & 49.1 \\
\hline U1406B-18H-3, 76-79 & 182.760 & 0.47 & 0.23 & 47.3 & 43.1 \\
\hline U1406B-18H-4, 76-79 & 184.260 & 0.65 & 0.22 & 42.4 & 46.5 \\
\hline U1406B-18H-5, 76-79 & 185.760 & 0.64 & 0.24 & 42.1 & 45.7 \\
\hline U1406A-18H-2, 78-81 & 186.590 & 0.53 & 0.22 & 39.9 & 47.5 \\
\hline U1406A-18H-3, 81-84 & 188.120 & 0.55 & 0.24 & 41.2 & 46.0 \\
\hline U1406B-19H-1, 76-79 & 193.421 & 0.86 & 0.25 & 57.5 & 35.0 \\
\hline U1406C-18H-5, 76-79 & 194.043 & 0.80 & 0.27 & 55.8 & 36.0 \\
\hline U1406B-19H-2, 76-79 & 195.010 & 0.85 & 0.28 & 71.5 & 24.7 \\
\hline U1406B-19H-5, 76-79 & 198.420 & 0.88 & 0.25 & 59.3 & 33.9 \\
\hline U1406A-19H-3, 78-81 & 200.074 & 0.66 & 0.24 & 36.6 & 48.3 \\
\hline U1406A-19H-4, 80-83 & 202.376 & 0.43 & 0.23 & 33.5 & 50.8 \\
\hline U1406A-19H-5, 76-79 & 204.636 & 0.68 & 0.25 & 42.2 & 44.8 \\
\hline U1406A-19H-6, 76-79 & 206.230 & 0.54 & 0.24 & 34.3 & 50.0 \\
\hline
\end{tabular}

* = archive-half sample; all other samples are from working-half sections. BIT = branched isoprenoid tetraether index, $\mathrm{MI}=$ methane index. \%GDGT-0 and \%crenarchaeol of total glycerol dialkyl glycerol tetraether lipids (GDGTs). 
Table T2. Sample positions, depths, and results, Site U1411.

\begin{tabular}{|c|c|c|c|c|c|}
\hline $\begin{array}{l}\text { Hole, core, section, } \\
\text { interval }(\mathrm{cm})\end{array}$ & $\begin{array}{l}\text { Top depth } \\
\text { (mcd) }\end{array}$ & BIT & MI & \%GDGT-0 & \%crenarchaeol \\
\hline \multicolumn{6}{|l|}{$342-$} \\
\hline U1411B-4H-2, 24-26 & 21.550 & 0.37 & 0.21 & 40.9 & 49.0 \\
\hline U1411B-4H-4, 24-26 & 24.550 & 0.31 & 0.21 & 41.8 & 48.4 \\
\hline U1411B-4H-6, 24-26 & 27.550 & 0.29 & 0.20 & 42.0 & 48.7 \\
\hline U1411B-5H-2, 24-26 & 31.540 & 0.37 & 0.20 & 44.3 & 47.1 \\
\hline U1411B-5H-4, 24-26 & 34.540 & 0.39 & 0.20 & 43.5 & 47.7 \\
\hline U1411B-5H-6, 24-26 & 37.540 & 0.28 & 0.20 & 43.0 & 47.8 \\
\hline U1411B-6H-2, 24-26 & 41.530 & 0.37 & 0.20 & 43.1 & 48.0 \\
\hline U1411B-6H-4, 24-26 & 44.530 & 0.32 & 0.20 & 42.6 & 48.5 \\
\hline U1411B-6H-6, 24-26 & 47.530 & 0.40 & 0.20 & 42.3 & 48.3 \\
\hline U1411B-7H-2, 24-26 & 51.620 & 0.39 & 0.20 & 44.0 & 47.4 \\
\hline U1411B-7H-4, 24-26 & 54.620 & 0.61 & 0.24 & 50.3 & 41.3 \\
\hline U1411B-7H-6, 24-26 & 57.630 & 0.30 & 0.21 & 41.7 & 48.5 \\
\hline U1411B-8H-2, 24-26 & 61.690 & 0.39 & 0.20 & 41.9 & 48.6 \\
\hline U1411B-8H-4, 24-26 & 64.730 & 0.47 & 0.22 & 45.3 & 45.7 \\
\hline U1411B-8H-6, 24-26 & 67.750 & 0.42 & 0.22 & 44.4 & 46.2 \\
\hline U1411B-9H-2, 24-26 & 70.560 & 0.38 & 0.21 & 42.0 & 48.0 \\
\hline U1411B-9H-4, 24-26 & 73.560 & 0.57 & 0.21 & 43.9 & 46.7 \\
\hline U1411B-9H-6, 24-26 & 76.560 & 0.46 & 0.22 & 42.9 & 47.2 \\
\hline U1411B-10H-2, 24-26 & 81.600 & 0.41 & 0.22 & 42.4 & 47.6 \\
\hline U1411B-10H-6, 24-26 & 87.600 & 0.44 & 0.22 & 40.9 & 48.3 \\
\hline U1411B-11H-2, 24-26 & 91.340 & 0.46 & 0.23 & 40.2 & 48.3 \\
\hline U1411B-11H-4, 24-26 & 94.140 & 0.42 & 0.23 & 40.4 & 48.4 \\
\hline U1411B-12H-2, 24-26 & 101.240 & 0.44 & 0.23 & 40.8 & 47.5 \\
\hline U1411B-12H-4, 24-26 & 104.240 & 0.55 & 0.25 & 41.9 & 46.4 \\
\hline U1411B-12H-6, 22-24 & 106.740 & 0.55 & 0.24 & 40.2 & 48.0 \\
\hline U1411B-13H-6, 24-26 & 117.380 & 0.59 & 0.26 & 42.4 & 45.5 \\
\hline U1411C-5H-2, 24-26 & 118.670 & 0.58 & 0.25 & 43.3 & 45.3 \\
\hline U1411C-5H-4, 24-26 & 121.040 & 0.64 & 0.25 & 43.6 & 45.0 \\
\hline U1411C-5H-6, 24-26 & 124.040 & 0.62 & 0.26 & 42.9 & 45.3 \\
\hline U1411B-14H-4, 24-26 & 124.890 & 0.60 & 0.26 & 44.2 & 44.5 \\
\hline U1411B-15H-2, 24.5-26.5 & 132.615 & 0.55 & 0.23 & 40.2 & 47.8 \\
\hline U1411B-16H-1, 33-35 & 140.730 & 0.41 & 0.22 & 39.7 & 48.9 \\
\hline U1411B-16H-4, 72-74 & 145.620 & 0.47 & 0.23 & 39.7 & 48.2 \\
\hline U1411B-17H-2, 24.5-26.5 & 152.395 & 0.52 & 0.23 & 37.2 & 49.7 \\
\hline
\end{tabular}

All samples are from working-half sections. BIT = branched isoprenoid tetraether index, $\mathrm{MI}=$ methane index. \%GDGT-0 and \%crenarchaeol of total glycerol dialkyl glycerol tetraether lipids (GDGTs). 